\title{
In the Labyrinth. State, Governments, and the Growth of the Public Debt in Italy in the Middle of 1980s
}

\author{
Leonida Tedoldi $\mathrm{a}^{*}$ \\ a Department of Human Sciences, Area of Political Studies, University of Verona, Italy. \\ ${ }^{*}$ Corresponding author's email address: leonida.tedoldi@univr.it
}

\section{A R T I C L E I N F O}

Received: 28-10-2015

Accepted: 13-02-2016

Available online: 20-02-2016

\section{Keywords:}

Contemporary History,

History of Political Institutions,

Italian Public Debt,

Political Economics,

Political Science,

Public Debt.

JEL Classification: H53, H7, N00

\begin{abstract}
A B S T R A C T
The ambition of this work is to rethink and present a possible path of historicalinstitutional investigation in relation to and with a critical comparison of solid economic, political and sociological research into the political causes of rapid increase of public debt and its 'instrumentalization' by coalition governments for the purposes of consensus, in the blocked political-institutional system, as the first Executives in the Italian Republic's history not led by Christian Democrats (DC) Prime Minister.

The reason for the decision to concentrate the analysis on a reduced portion of that decade - and therefore chronologically not going past 1988-89, the year of a passage to a different phase for many aspects - responds to the intention of concentrating the analysis and delving into the sources (archival and institutional sources, but also archives of political parties).

Italian State has always lived above its means, with a constant imbalance between income and expenditure and at the same time expanding its distance with respect to society (but the debt was paid by social groups that took advantage of it), a process that triggered off a perennial crisis of representation and strengthened the instability of relations between political institutions and society. Moreover, public debt crises, as historical research suggests, are always crises of institutional legitimization and require a redefinition of the ways in which sovereignty and political power are exercised.

Thus, the article investigates the impact of the 'political use' of public debt by italian governments on the relationship between the State and society.
\end{abstract}

(C) 2016 The Authors. This is an open access article under the terms of the Creative Commons Attribution License 4.0, which allows use, distribution and reproduction in any medium, provided the original work is properly cited.

DOI: http://dx.doi.org/10.18533/rss.v1i2.12

\subsection{Introduction}

The idea of this research stems from an interest in the issues raised in the period of the public debt's peak growth within the institutional and political mechanisms of the Italian State. From this viewpoint there is no scientific literature available in Italy, while there is considerable political and economic literature on issues in the State's budgeting policy and on the economic reasons for the growth of the sovereign debt. (De Ioanna, 2014, Verzichelli, 1999)

This threefold historical-political-institutional approach is an attempt to understand, through a series of historical research methods based mainly on archival sources (institutional, but also the archives of political parties) and on scientific and sociological literature, the risks, limits and negative impact not only of governmental economic policies, but especially of the overall "malfunction" of the State apparatus, for the purpose of building consensus. 
The goal is to analyse the reasons of political factors/errors committed by successive governments, the first Executive in the Italian Republic's history not led by Christian Democrats Prime Minister (Presidente del Consiglio). As political literature has shown, competition between parties makes borrowing an always attractive option - especially in bicameral systems - (Downs, 1957; Heller 1997; Santagata, 1995), caught though in Italy between the persistent aim to rehabilitate public finances and the aims of 'political exchange'. The Italian case shows well how the debt crisis is always an institutional legitimacy crisis, but can also be a strong tool in the hands of governments to take action and exert pressure on the Parliament.

Basically, it's a work of (political and institutional) history that is also meant to encourage the relationship with a deeper political analysis of the topic of debt growth, and its use in terms of policymaking by governments in Italy, one of the Western countries most affected by this problem. From this point of view, an analysis of the 1980s, I believe, is necessary and unavoidable, as the debt started to grow by about $30 \%$ over GDP, which will form the "hard core" of the substantial Italian public debt.

The path between the fiscal State crisis and the construction of the 'debtor State' started towards the end of the 1970s (Ferguson, Maier, Manela, Sargent, 2010). At that time when, on the one hand, the inflation growth allowed the State to become indebted at real decreasing and at times negative costs, whilst on the other, the idea of the debt growth at the expense of the future was reinforced, in the conviction that the State would always have had full control over money and the 'real economy'. (Brosio, Marchese, 1986). This vision was functional to the political process generated by the historic compromise and the season of national solidarity, which on the economic level was supported on the 'exchange' between defence and containment of the cost of labour, on the one hand, and increase of public investments and expansion of the guarantees of social rights on the other. Moreover, the distributive power has always prevailed over the 'extractive' power, of the collection of taxes, which became evident in the early 1970s, when major spending programmes took shape and accelerated from the end of the decade. (Brosio, Marchese, 1986; Fausto 2007). The controlled indebtedness was used to fill a gap between the direction of the economic governments' policy aimed at emphasizing recourse to the objective of cure of the public finances and the aims of political exchange with society.

Western democracies, like Italy in the 1980s, well knew that the debt generated a relationship with the citizencreditors - the sociologist Wolfgang Streeck called them the 'State people' - that was very complex which concerned in the first place the relationship of trust, consensus and pursuit of a socio-symbolic collective imagination. At the same time, governments knew that to support a democratic State with a high debt, the creditors had to be satisfied. But, if the State had proven to be only a longa manus of the creditors, it would have run the risk of triggering a process of delegitimization of the political institutions. (Streeck, 2014)

Therefore, the article is divided into three sections which represent the most critical phases of the relationship between debt growth and the political difficulties of the State and Governments, which have thrived on the 'rational illusion' of being able to manage the public debt, without having to worry about the consequences on the future generations.

\subsection{The limits of governability}

At the end of the 1970s, Italy faced the second wave of recession, due to the oil crisis, with its already visible inefficiencies, on the one hand, and with the excessive power of its administration machine on the other, which was leading to serious problems in the public finances and the structural deficits that had generated inflation. Public political action had dilated expenditure - which was going through its third cycle (1978-1985) of expansion - in search of consensus 'to the limits of governability' (Salvati, 2000), as maintained by some authoritative commentators, causing a problem of legitimization which was destined to become even sturdier. In other words, that incapacity of the governments to force social demands in the resources available in a fiscally controlled context was becoming consolidated. (SR, 1978; Romanelli, 1997)

On the institutional level, from several sides there had forcefully emerged the proposal, or better, the invocation, of restoring a correct relationship between the Legislative, the Executive and the Judiciary, in which the DC (Christian Democrats) had the responsibility for creating a new civil agreement, supported by an economy governed by its institutions. These problems, mentioned here briefly, were also part of a global context in which a new orientation in the international monetary policy was prevailing. The end of the Keynesian-Fordist paradigm was being outlined to the advantage of the growth of (liberal) monetarist policy which met the wishes to overcome the old interventionist recipes which had failed to fight stagflation. To meet high inflation and thus respond to the need for stability, the discount rates of the Central Banks were increased and in this way the offer 
of liquidity on the market was reduced, producing a reduction in inflation. It was the assertion of 'supply side economics', the pendulum was returning to the market. (Tanzi, Schuknecht, 2000)

Between the end of the 1970s and the start of the following decade, although on the economic level Italy was still expanding and in the middle of the cyclical impetus of investments, conversely the exhaustion of the long phase of connection between society and public intervention was appearing, as well as the weakening of the preeminent role of economic and social policy in pursuing development and affluence. At the same time, the policies of social expenditure had not modelled social stratification, keeping sectors of the population now directly dependent on the aid of the State. In this situation, the political and institutional system was going through a period of great uncertainty, also characterized by strong competitiveness between the Christian Democracy and the Socialist Party and by the usual political relationships based on agreements no longer existing, in which the primacy of politics, which in the previous decades had favoured and in part reinforced the reforming attempt of the 1960 s, became narrower.

Moreover, the social tensions still linked to the difficult passage between the political season of 'national solidarity' (DC and PCI political agreement) and the simultaneously more complex and weaker one, of the four party system had not completely vanished. In actual fact, a profound phase of change was becoming consolidated. The end of the experience of the great encounter between the DC and the PCI had then accelerated the deterioration of the institutions, which at this time were unable to manage the public governance of the economy in the face of an exceptional season of increases in public expenditure, as in that of '79-' 80 , which had had strong effects on the deficit of the State. (Craveri, 2004; Franco, 1993; Fausto, 2007). From the more internal point of view in the institutions, Sabino Cassese maintained in those years that it was not the 'Leviathan' State that was in difficulty, but that in actual fact a 'fringe' of the State as regulator of the economy was changing, as was happening, during the season of 'supply side economics', in other European countries. (Cassese, 2014)

Moreover, the structural difficulty of Italian governments to sustain the development of a solid policy of expenditure containment is now well known. Indeed, this context was increased by a situation of uncertainty, in which the central role of the parties was absent and the President of the Republic, guarantor of the institutional balance, would have become an increasingly less discreet director. Between 1978 and 1979, the increase in indebtedness, to quote the words used by the Court of Auditors (Corte dei Conti), alarmed by the growth of the phenomenon, due at that time to a reduction in the rate of income growth, did not lead to a reaction of the government that activated an action to contain the expenditure growth, especially of that for 'social security' and in general for welfare. (CC, 1979; Riva, 1979)

However, as early as 1979 a definite slowdown of the tendential growth of the financial demands of the public sector had appeared, although this slow down did not seem to reflect a change in the basic trends of the evolution of public finances (Riva, 1979). These were the years, in short, in which the middle classes consolidated their social entrenchment, which had developed under the constant drive of a high level of social spending. In 1980, which started marked by the great instability of the Executive led by Francesco Cossiga and which recorded a considerable increase in the public debt, of more than $20 \%$ compared to the previous year, the Censis, with extraordinary punctuality, reported, once again, the chronic difficulties of the governments such as those relative to economic planning (Censis, 1980), the administration of the social policies and some collective services, such as transport and energy, together with the absence of a real territorial planning policy in the South of Italy (Salvemini, 1992). In this context, outlined thus, collateral circuits of a private type in the sector of education, health and the social services emerged, now highly visible.

On the institutional level, the separation between government and central administration on the one hand and the system of the regions and local autonomies on the other increased and, at a more purely political level, the parties were directing their efforts in the search for consensus mainly towards the middle classes. These classes had now pervaded the structures of the public and private bodies and were creating the presuppositions for the development of small and medium-sized industry and commercial intermediation and were thus also an important part of self-employed work. The most immediate consequence of this situation was the advance of welfare policies towards families and businesses.

In those years, Italian society expressed 'more demand than logics for expansion' (CC, 1979), which intersected with phenomena of social demands, on the one hand, and with the social needs of the technicians and middle management of large and medium companies on the other and also with the Italy of the small and medium sized productive activities which now represented an important part of the country's economy.

\subsection{Central Bank and Treasury}


During a period of about twelve years, which led to the facts of 'Tangentopoli' in the early 1990s, the public debt was to grow more than the positive primary deficit and was to pass from about 59\% of the GDP of the early 1980 s to over $100 \%$ in the early 1990 s: the leap of $40 \%$ in six-seven years, from 1983 to 1989 , was to create the hard core of the Italian sovereign debt, bringing back the impact of the debt to levels similar to those of the end of the 1890s. (Francese, Pace 2008; Balassone, Francese, Pace, 2013 and Artoni, 2003). In that very difficult period in the first half of the 1980s, a strong trend could already be seen in some sectors of society - linked to inflation - towards channelling the flows of savings towards the short-term public debt. This orientation was very warmly supported by the government.

At the same time, on the more institutional level, the intervention of the Central Bank (Banca d'Italia) in the relationship with the Treasury on the management of the public debt was taking shape. From several sides - in Parliament and in the poliical debate - including some representatives of the Communist Party, the need to reinforce the powers of the Central Bank was maintained. (Marinelli, 2011). Until that time, the Treasury had been responsible for expenditure, whilst the Bank for its funding (and also established the rates of the BOT (Short-Term Ordinary Treasury Bonds) through managing the State Treasury at the issuing bank, guaranteeing a support of liquidity for the 'overdraft' created by the Treasury. Under the pressure of the difficulties of the sustained growth of the State financial requirement, the urgency to implement coordinated policies to reduce inflation, without sacrificing employment, was rekindled. (Fausto, 20007).

The Governor, Carlo Azeglio Ciampi, taking advantage of the important agreement between the government and the Central Bank, succeeded in addressing his efforts towards reinforcing the autonomy (and the role of the administrative authority) of the Central Bank with respect to political power, already undertaken, with alternating fortunes, by his predecessor. For many years, former governor Paolo Baffi had been greatly in favour of the creation of money (the primary function of the Central Banks) being exercised in complete autonomy from the centres where expenditure was decided. (Cama, 2010).

In this way, that important political phase of the monetary authorities started which led to the 'divorce' of the Bank of Italy from the Treasury; i.e., when the mechanism of the subscription by the Bank of Italy of the public debt securities not placed on the market was superseded once and for all, meeting the constitutional rule that set precise limits on the direct monetary financing of the public deficit. Therefore, with the attempt to make the 'difficulties' of financing the deficit transparent, the responsibility of the political class would also have been shown: the public debt could not be financed in an uncontrolled way on a monetary base, so credibility had to be returned to the Bank of Italy. (Cama, 2010).

On the one hand, the obligation placed by the agreements of exchange defined on entry into the EMS in 1979, which no longer allowed the Bank of Italy to finance the state deficit, had weighed on this decision, but, on the other hand, so did our Central Bank's scarce sharing of the political objective of the Treasury of 'minimizing' the cost of the debt. In this way, the responsibility of the Treasury increased in deciding the debt policy and the characteristics of the securities issued. The Minister of the Treasury in the Arnaldo Forlani government, Beniamino Andreatta, pushed by the need to contain the expansion of banks' liquidity, to keep inflation stable and at the same time to increase tax pressure, therefore put the debt on the market with the main intention of guaranteeing positive real interest rates. (Salsano, 2009; Andreatta, Pandolfi, 1980)

In other words, the Bank of Italy no longer took part in the primary auctions of placement of state bonds as a last resort lender (to buy the unsold State bonds or to control the auctions in the event that the offers by private investors were too low), leaving the field open to private banks and operators, but also to financial speculators. The Central Bank, on its part, could no longer be forced to finance the state deficit with a monetary expansion policy. The intention was to modify the regime of the economic policy at a time when the government was strongly looking towards growth policies, supported by low real interest rates and a weak rate of exchange.

In addition, the government hoped, but also the top management of the Bank of Italy, that this change of 'monetary constitution', to use the expression of Carlo Azeglio Ciampi, would lead to a profound transformation of the procedures for the expenditure decisions and those for the distribution of income. (Valente, 1990; Franco, 1993)

The 'divorce' re-launched both the central role of the independent technical judiciary, acting as a counterweight to the bodies of political power, and the institutional role of the Parliament and of the government, summoned to respond in the case that the main source of financing the deficits were no longer to exist. At that time, compared to the other political subjects on the agenda of the Forlani government, the problem of containing the deficit appears the object of an open discussion in the political centres, but without taking on the characteristics 
of a real emergency; then, in the period of a few months, the growing preoccupation pushed towards some changes in the government's action and in the decision-making process of the budget. (Marinelli, 2011).

As early as 1982, the dangers of a real non-governability of the public finance appeared obvious, at least at the level of parliamentary debate and these dangers were also highlighted by the Court of Auditors. Precisely for this reason the introduction of an efficient general coordination of the public finance policy was invoked by the representatives of the parties, not only in the government, aimed at rapidly intervening with an action to contain the deficit, on that part of the expenditure 'not directly controlled by the State and entrusted to the responsibility of other decision centres of the public sector.' (CC, 1982).

On the political level this intervention of the Court seems to show the profound weakness of the governments and the 'sustainability' of the Italian institutional system. Indeed, the last part of the $8^{\text {th }}$ Parliamentary Term (1980-1983) was dominated precisely by the subjects of public finance. The growth of public deficit and debt quickly highlighted the limits of autonomy of the government's action.

\subsection{In the labyrinth}

When Giovanni Spadolini (Republican Party) became Prime Minister, the premises, then ignored, for a political season which would have led to the assertion of the 'verticalization' of the government's action were created, in the attempt to reach a rearrangement of the Prime Minister's office, the topic of the growth of the public debt had already vivaciously emerged in parallel, in some way, with the attempts at institutional transformations. Between 1980 and 1982, with the increase in volume of State bonds, the BOT attained one-third (about one hundred thousand billion Lire) of their total, making the debt 'shorter', as a consequence of the brief due date of the bonds, but very appetizing on the social level, for small and large savers.

During the parliamentary debate on the act of 'confidence' in the Spadolini government, which closed the season of great instability of the Cossiga and Forlani governments, the need for reforms on economic matters, which had been postponed after long discussion following the work and proposals of the Giannini commission, as well as the decision to establish a session for the budget and a commission for the control of public spending, that could guarantee the respect of the obligation of the budget indicated by art. 81, was re-asserted. (Lanzalaco, 2005; Spadolini, 2002). This direction was then confirmed in the 'institutional Ten Commandments' of the second Spadolini government. The difficult path of the Parliamentary Term and the Executives led by Giovanni Spadolini was conditioned immediately by the permanent nature of the spending decision mechanisms outside governability, although he had insisted on discussion in the organizations of the government around the problem of the return to a normal relationship between the 'times of the decisions and those of implementation' of the economic policies with the aim of restoring functionality to the institutions and therefore value to politics itself. In any case, the Spadolini government succeeded in imposing a decrease in the rate of inflation from $20 \%$ to $16 \%$ and containing the debt below 50,000 billion, as well as a reduction of the balance of payments. (Spadolini, 2002)

In addition to this picture, a new phase of recession was looming which led to a delay in the economic manoeuvre which contributed to weakening the national currency and therefore fostering the choice of opting for a controlled devaluation within the limits of $2 \%$, but which was then to become $6 \%$. In addition, the serious problems that prevented the action of recovering the institutional control on the centres of expenditure which pressed on the needs of the State coffers had clearly appeared. In the face of dealing with these problems, the political pressure allowed various approaches - which was also a cause, as is known, of the fall of the second Spadolini government - by the two ministers most concerned: Andreatta at the Treasury and Rino Formica at Finances. (Salsano, 2009).

The former tried to stubbornly maintain the line of rigour even after the first signs of recovery and maintained the need to invert the tendency towards expansion which would allow respecting the estimates of expenditure, whilst the latter called for an expansion policy, that would shelter the State from the risk of 'derailing the train of public finance', as the Secretary of the Socialist party, Bettino Craxi, had also feared on several occasions. (Craxi, 2000) Formica himself and Gianni De Michelis had several times been engaged in a political controversy against the Treasury, accused of not being able to control the effective dynamic of expenditure and failing to provide credible estimates of cash to Parliament. In those years, Craxi himself had also hoped for the introduction of policies of intervention on the dramatic social inequalities of the country, but without ever mentioning the reinforcement of a solid public debt policy. (Craxi, 2000). 
In these circumstances, Andreatta highlighted the political need for the government to recover the sovereignty 'humiliated by external obligations', through the proposal of activating a 'return process' which would be able to govern the problems caused, according to him, by the growth of the Welfare State and the entrepreneur state, but also by the failure to reduce the increase of the deficit generated by the interest payment on the debt. This debt had already been transformed, according to Andreatta, 'in effect and cause of the deficits' and this situation, at the political level, imposed a serious reflection on the errors of evaluation, but also of direction, of the previous years. (SR, CD, 1982).

However, the second Spadolini government also encountered numerous difficulties on the more substantial part of the economic manoeuvre in terms of recovery proposed by the Prime Minister. Although attention had increased on the control of the spending centres (but not on the side of the income), in the directions of the government bodies the 'return policy' did not yet represent a real priority and this attitude highlighted the political and structural weakness of the Executives in the face of a need of indebtedness by the State that was not decreasing. Giuseppe Costamagna, a member of Parliament of the Christian Democracy party, had maintained in Parliament, with a rare gift of synthesis, that 'the tiger had unsaddled the State' i.e. that the State's need for indebtedness had become so pressing as to force it to issue bonds with increasingly higher rates of interest and much higher than the rate of inflation. (CD, 1982).

From several sides, the government was asked to rapidly intervene to lengthen the life of a debt that remained 'short', also following the proposal of the Minister Formica to activate a sort of 'concordat' with the creditors holding three and six month BOT on their transformation into debts collectable only in the medium-long term. However, this season - marked by the scarce politics impact on the now evident 'social segmentation' which was leading to a crisis of the public government of the economy and the very ability of governance by the Executive is marked by the first real attempt at containing the public deficit, started with the including in the Budget an extraordinary manoeuvre, which could overcome even the 'opposing and quarrelsome attitudes' of the Ministers of the Treasury and of Finances. (Censis, 1983).

The manoeuvre imposed a strong political direction on the problems of the control of public spending and planning public finances, even though the political practice, which was defined in Parliament, was recurrent and often turned out to be inefficient, of financing new expenditure through the 'reversal' from the fund for the depreciation of the public debt, in essence, therefore, financing them in deficit.

Indeed, the second Spadolini government did not succeed in opposing a 'micro-distribution' policy and therefore once again reached a spending growth that was to prove the failure of the manoeuvre, and the tendency to consolidation of the poor structural sustainability of the administrative body that now had to be dealt with in a more rational way, without alibis of any kind. However, the deficit of the Public administration had exceeded $10 \%$ of the GDP, a far higher percentage than that of the other European countries ${ }^{1}$. The passage from the fall of the Spadolini government to the establishment of the short-lived Fanfani government did not contribute to the establishment of an advance on the theme of the expansion of the debt.

The 'Spadolinian' model of economic emergency which proposed moral rigour and moderate austerity had always been countered by, on the one hand, the Socialist model, based exclusively on the fight against inflation and, on the other hand, by the Christian Democrat model, centred on the reduction of the deficit and public debt. In addition, the Auditors' Court had once again strongly criticised the government due to the now macroscopic continuation of decision mechanisms of expenditure implemented outside the functions of the Government and Parliament. (CD, SR, 1984; AIS, 1984).

In essence, the political idea of centralizing the decision-making process depending on a control of spending, to be realized through the manoeuvre of the budget, was in an advanced state of crisis although it had grown stronger only in the 1970s. It had to clash with the polycentric structure of the relations between government and Parliament and therefore did not succeed in providing an adequate or even partial answer.

The political theme of the public debt appears crushed and amplified by these relations and it becomes, at this time I believe, a real political subject and no longer almost solely economic. At the beginning of the political season of the Craxi government, the country experienced a great moment of productive impetus, which pushed employment to grow and reduced inflation through manoeuvres of spending cuts and important actions such as the abolition of the cost-of-living index; in that period the political attitude of government was not to damage the phase of expansion. The budgets of the individual administrations were controlled, at least on paper and

\footnotetext{
${ }^{1}$ In industrialized countries, it fluctuated between $1 \%$ and il $4 / 5 \%$.
} 
there were no privatizations. The economic manoeuvres, however, became more effective on the level of reinforcing the role of the government and of parliament. (Verzichelli, 1999).

However, the micro-budgeting, which from a certain point of view succeeded in guaranteeing keeping networks of supporters in the Executive and in Parliament, did not pursue a real strategy of containing the deficit whilst, on the other hand, 'the action of political players who used and developed the public debt in exchange for pure consensus' was increasingly reinforced, as shown by many indicators. More in general, the reduction of inflation and economic expansion were considered priorities with respect to the problem of the needs. According to political research these were the years in which the decision-making style of the governments changed and conditions of stability were concretized. Even though in a context of harsh opposition between the majority and the PCI (Italian Communist Party) on the question, as is known, of the cost of living index (Verzichelli, 1999).

In any case, the increase in public spending - which between 1980 and 1985 grew at an annual rate of close to $22 \%$ and therefore above the nominal growth of the GDP, although it remained below the European average and the increase in the indebtedness of the State (together with the interest expenditure) guaranteed paradoxically for the parties more strength in the management of power, without it being possible for the oppositions, especially the Communists, to develop an alternative policy (Goria, 2004; SR, 1985/1).

In this way, obviously, the reasons and the political roots of such an indebtedness and the continuing of sustained public spending was neglected, even of that for the interests on the debt, but also of the difficulties of a fiscal system yet to be consolidated.

This was at least until the 'Goria Plan' of return on 1984. With this Plan of zeroing the deficit, the aim was the reduction, to the potential halving, of the stock of public debt that was becoming a 'natural political objective' in a process of complete recovery of public finance; even if then in the immediate no decision was taken by the government in this regard. Indeed, the problem was to once again and rapidly be subordinated to other needs of the State, although the partial failure of the process of rationalizing spending was very present and made evident even before Parliament. In addition, in the discussion in the government coalition, this theme was translated into a vague proposal of progress in the reduction of the debt, followed by not too detailed attention to the political problems determined by interest payments on the debt, which in those years was growing by about $25 \%$ per year. (Goria, 1985, FBC, 1984; SR, CD, 1984).

Therefore, at this time in history, the main basic political problem for the government was the objective of containing the deficit whilst the annual increase of the public debt, which was growing constantly, was not the object of in-depth political analysis, although the real problem was also the 'self-nourishment' of the debt. In other words, the indebtedness growth was given mainly by the gradual increase in spending for interest caused by the raising of the rates of interests of the bonds. Since the beginning of the 1980s to the beginning of the next decade, the interest expenditure passed dramatically from about $5.4 \%$ of the GDP to more than $11 \%$, compared to an average of Western countries which was maintained at around 4.5\% (Franco, 1993). However, although the gravity of the situation had now been made clear from several sides, including and above all by the parliamentary oppositions (but not always insisting on this subject), the political use of the debt still remained a resource of governments' consensus which was risky but nevertheless a resource (Pandolfi, 2000). In the meantime, however, relations between the Minister of the Treasury Giovanni Goria and the Minister of Finances Bruno Visentini became exacerbated. (Pandolfi, 2000)

The latter was entering into conflict on the merit of the actions by the government, deemed ineffective, to redefine the relationship between the Bank of Italy, the Treasury and their public debt policy; this friction was to arise in 1985 and reach its height in 1986.

The Republican was always a critical voice of the government policies towards the Central Bank (and of poorly fighting tax evasion) and above all an ardent supporter of a clear reintegration policy of the roles and functions of the Executive and Legislative, occupied, in his opinion, by the political parties.

It was precisely for these convictions, that he thought that the public debt had to be attacked, as it was the cause and consequence of unbalanced public finances, using the tax instrument as an element of pressure to reach, in not an excessively long period, its consolidation (Delalande, 2011). These were political aims which by no means were in harmony, and they could not have been at that phase, with those of Craxi and Goria. Moreover, the rigour policy had high costs in electoral terms. Considering that in 1984, when the debt/GDP ratio was about $74 \%$ compared to the $69 \%$ of the previous year and when $70 \%$ of the BOT and $70 \%$ of the CCT (Treasury Credit Certificates, Long-Term Treasury Bonds) (whereas in 1977 it had been respectively $24 \%$ and $22 \%$ ) belonged to 
families and companies, including financial ones, instead of banks and the Bank of Italy, it is fairly clear that the policies on the debt had already taken on the form of a political instrument of consensus. (Verzichelli, 1999)

On $16^{\text {th }}$ November 1984, Rainer Masera, the Director of the Research Department of the Bank of Italy, answering questions of journalists, maintained that 'the high level of the real rates of interest (which had directed families' savings towards financial assets) had allowed in recent years having an enormous amount of public debt absorbed by families, consenting the monetary base, the currency and credit to be kept under control' (Merli, 1984). Sometime earlier, Guido Carli had stated that 'through the public debt Italian families had made the cultural choice of the market and the continuation of the public debt in the wallets of the less affluent social classes represented the guarantee of democracy.' (Carli, 2008). This consensus generated by the machine of the public debt entailed a support for the government - the nine governments that followed on one another in the 1980s alone - but also, we believe, a reinforcement of the Executive regarding the role of controlling the management of the budget and the financial coverage of Parliament. This role had become consolidated with the reform which followed the new discipline for the formation of the budget started in 1987 and the agreement in 1983 between the President of the Senate Amintore Fanfani and the President of the Chamber, Nilde Iotti, on the establishment of an information system connecting the two Chambers and the State General Accounting Office.

In addition, the fact that, in these years, the policy of the Treasury and that of the Bank of Italy aimed at replacing banks by investors not of the banking sector in the position of creditors to the State must not be overlooked. It is sufficient to consider, in this sense, the favourable conditions set on the subscription of these securities: high yield offered by public securities, absence of risk in such an investment, the tax exemption of this income as well as anonymity.

In this way, that acceleration of the dilation of the debt - and above all of the management of spending for interest - which could no longer be traced back to the end of the decade within a picture of full sustainability, against public spending, net of interest, but which remained within the European parameters, became stronger. Therefore, 1984 was a year of great political contrasts on the policy of the public debt. On the one hand, the government parties, DC, PRI and then PSI had undertaken the attempt to impose a policy of rigour but without acting on those dangerous elements which were causing the massive recourse of many business groups, and political clans, to the public debt. On the other hand, the Communist Party did not accept the approach of a rigorist policy of the government, because it deemed that the public deficit and the public debt were not the expression of an excess of social consumption', but had rapidly become a powerful instrument 'of income redistribution to the detriment of the employed worker' and of the economic development, favouring new and purely speculative wealth (Ledda, 1984).

At the end of 1985, however, the policy of the debt reached its most delicate moment. In the meantime a sharp decline in income loomed up (and a dizzying increase in tax evasion) and the public debt was increasingly becoming an instrument of 'redistribution' policy, which imposed a choice on the attribution of the burden of the debt and then it appeared evident that its management had to be tackled by implementing an adequate administrative instrumentation (SR, 1985/1).

The session of the presentation of the manoeuvre and the future directions of the economic policy made by Giovanni Goria on $28^{\text {th }}$ November before the Senate, represented a central political key to understand that the public debt was not considered an important part of the families' investments and therefore of the overall development of society, on condition that it was kept within limits deemed 'acceptable'. 'There is only one hypothesis', maintained Goria, 'that is appreciable for our future regarding the management of public finances and the public debt: that of stopping at a level where the public debt, as well as the real property and the other elements of saving are part of the families' increase of wealth, i.e. they are considered as part of something that is managed in the best way possible, without dynamics, without speculative factors (SR, 1985/2).'

In addition, the rejection by Goria of the indication of many experts and of economic milieus, which had forcefully emphasized that real rates of interest above the rhythm of economy growth were self-feeding the debt (and therefore the interest expenditure and, from there, the deficit as well), had moved the Executive away from the directions of the Bank of Italy as well, for many aspects (SR, 1985/3)2.

\footnotetext{
${ }^{2}$ In those circumstances, the Minister Goria maintained that the debt was not to be considered a political problem, because its reduction would have taken place after the block of overall income at about $38 \%$ of the GDP, lowering the current expenses from $36.6 \%$ to $32.5 \%$ (excluding those for interest) and those in the capital account from 6.8 to $6.5 \%$.
} 
Moreover, over a period of ten years, the holders of the stock of the debt had changed drastically: from the prevalence of banks and the Bank of Italy to families and businesses ${ }^{3}$ and, in essence, this situation was accompanied by the clear formation of a class of renters, of a social block which is fed progressively by the State, through the purchase of debt securities, to increase their income and at the same time recreating more debt (Locatelli, 1985).

In 1985 the Public Debt was approaching 90\% of the GDP. That year, the perception of the political problem was therefore widespread in Parliament, as shown by many speeches. The awareness in different parliamentary groups that there was not yet an acceptable and pursuable policy of recuperation was equally widespread. The fluctuating action of the Minister Goria was the emblem, and not the only one, of this political attitude towards the problem now more than preoccupying, in view of the dimensions that it had taken. From the end of 1985 a new conflict was exacerbated between the Bank of Italy and the Treasury which was then to reach its height in the affair of the 'Black Friday of ENI' and the collapse of the Lira4

It now seems clear that the process in the course of verticalization and delimitation of the decision-making area of the government to a small number of institutional actors had also led to a very precise political use of the public debt, with the aim of maintaining the consensus, but also the constant legitimization of the government now transformed into a place of permanent inter-party conflicts - with the effect of amplifying the decisionmaking capacity of the Executive, as an autonomous Legislative.

If it is probable that the choice of indebtedness was also determined by massive recourse to public spending to stem the pressing criticism of the Communist Party and by the pressure of the interests in society, that were contrary to any scaling down of the debt, this debt policy became the heart of the search for consensus in those years (Amato, Graziosi, 2013).

For this reason, keeping a high Public Debt capable of causing a constant transfer of wealth into the hands of its new holders also guaranteed at the same time strong consensus in the middle classes. From another point of view, it was also a response to the political-social unproductivity of coalition governments, which were incapable of consolidating political power and which therefore imposed on the political class the search for new forms of legitimization of the action of the government.

According to the data of the Treasury of those years, the expenditure for real interest on the debt stood at about 23,000 billion, equal to $3.7 \%$ of the GDP and in 1986 this expenditure was equal to two-thirds of the need of the public sector. In the face of this situation, now macroscopic, in which attitudes of great preoccupation appeared from several sides, once again two different political directions became consolidated regarding the action of reducing the debt: on the one hand DC and PRI hoped, once again, in a rapid reduction of public spending and on the other the PSI would have liked to reduce the interest of BOT and CCT (Carabini, 1985). Beyond these contrapositions, however, there remained the political need to reinforce, without any more alibis, a direct relationship with public opinion, at a time of great crisis of the Keynesian policies and of the social state and the difficulty of the parties to 'restore the impulses of civil society into the institutions'. In addition on the institutional level, the strengthening of that 'regime of the Prime Minister' had now taken shape, supported by Bettino Craxi (Socialist), continued in part by Ciriaco De Mita (DC), which aimed at a unifying, arbitral and fiduciary role of the President of the Council of Ministers vis-à-vis a collegiality of government expressed mainly in the Cabinet (in which the Minister of the Treasury held the most important role). (Calise, 1997; Mastropaolo, 1996; Fabbrini, 2000).

Therefore, acting on the public debt, as we have seen so far, was useful in maintaining consensus with respect to the crisis of the political parties as collectors of public opinion and as competitors in determining national policy on economic problems which no longer allowed recovery, at least equal to the levels prior to the oil crisis. More in general, in this sense, the words of Giovanni Spadolini, pronounced in the Chamber of Deputies (Camera dei Deputati) on $30^{\text {th }}$ August 1982, have to be recalled: 'the political institutions must have an area of authority and consensus that goes far beyond those of the parties that give rise to the majority.' (Spadolini, 2002).

At the same time, it was increasingly clear to the government how it was necessary to review the institutional framework within which the public finance decisions operated and the objectives that the public action in the economy pursued. However, the inadequacy of the instruments of control over public spending made the

\footnotetext{
3 At this time, private individuals, the 'families' (middle class more or less) in particular, held about $46 \%$ of the Securities (essentially issued by the Treasury), 51\% belonged to banks and 3\% to insurance companies.

${ }^{4}$ On 19th May 1985, a purchase order of the Istituto San Paolo of \$125 million on behalf of ENI, for the extinction of a debt, was completed on the day of the negative record of the Lira on the Dollar, despite the warnings of the Bank of Italy. The Lira collapsed and started the process of devaluation and, on the political level, harsh institutional conflicts arose.
} 
capacity of the government even weaker, reinforcing the constant postponement in an almost rhetoric and obstinate form, of the policies, recuperation, and of the reduction debt (Goria, 1985).

In 1986 the phase of expansion of the economic cycle was reaching the end, the stalemate situation was a reality and the rationalizing action of the financial policy, supported by the Treasury, contextually with the less than brilliant process of containing spending, came to a standstill. The now open conflict - which we believe was triggered off in the previous two years - following the exposure by the Court of Auditors, after the annual analysis of the statement of account of 1985, of a cover, deemed 'fictitious', of some laws on spending, did not favour by any means the stabilization of relations between bodies of the State, Treasury and government; on the contrary (De Dominicis, 1986). It had not allowed undertaking a real path of recovery from the deficit ${ }^{5}$ (CC, 1986). The Court of Auditors had for some time been denouncing that public accounts were not homogeneous and had started an attempt at 'normalizing' the need, making clear to the Craxi government the numerous criticalities and the finance imbalance, especially in social security, as well as in regional finances and in particular for health system. In 1986, the government of the Socialist leader, now politically fragile and divided, had shown in the Budget a triple emergency: the correction of the natural trends of the public debt, the reorganization of the policy on salaries and a solution to the monetary crisis.

\subsection{Conclusions}

The overall failure of the recovery policy, represented by the failure to invert the trend with regard to the trend of expansion of the overall public debt, was the fruit of a contradiction between the ambitions of an Executive reinforced both at structural level and in its decision-making style, and a general system of interactions which was becoming undone between the government, Parliament and the parties and where the typical limits both of a political and institutional nature were emerging. In other words, a situation of stalemate started which caused a gradual restriction of the single-party government. This is the period that shows the consolidation process of oligarchies in Italian society.

This also meant that the 'sub-systemic' processes of development of the strategic conduct of the main Italian industrial and financial groups were producing new phenomena of centralization of the economic and social leadership, also causing widespread forms of selectivity and, at the same time, large areas of social exclusion.

Within this context, the logic and the purposes of 'political exchange' were fully included in the political use of the public debt; in this way privileges were established for some social groups, the middle-upper classes, which had channelled social mobilization towards strengthening the sectors of advanced tertiary and production and also towards the rapid growth of small industry.

However, in the face of a good economic situation in which the economy grew, inflation decreased and the Stock Market showed good resistance, there could be seen, contrary perhaps to what observers could think, a strong increase of the already high interest of the general public in State securities, then confirmed the following year by the most authoritative press; 'BOT full steam ahead' to mention the headline of an article published in those years, although it was in 1986 that taxation of securities started ${ }^{6}$. In this situation, although the consensus around the 'party of expansion' was definitely declining and the consensus around the rigour policies had sharply increased, that inertia of the political class had not yet disappeared, especially in the face of the change under way of the political powers from the authorities to the managing authorities of services. (Crainz, 2012).

This 'inertia', perhaps better limit, had often supported the conviction of governments to act above all on controlling the increase of public expenditure - which moreover in 1987 broke through all estimates, even in the presence of a consistent increase in revenue - with the awareness that the growth of the Public Debt could guarantee a constant social resistance indispensable for the legitimization of the political system in society, at least until the start of the 1990s. (Censis, 1987).

In actual fact, the self-nourishment of the debt had cracked this political strategy of the government which had made the public budget a place of the 'financial illusion' according to Paolo De Ioanna (De Ioanna, 1993), so that at the end of the Craxi government, in the face of an inversion of trend of the increase of the State's need and the

\footnotetext{
${ }^{5}$ The need that had declined in 1984 once again shot skywards in the following years, also causing an increase in the ratio between the public debt and the GDP.

${ }^{6}$ The auction of BOT at the end of the month concluded with the subscription, above all by Italian savers, of 20,316 billion offered, of which only 952 were subscribed by the Bank of Italy. According to some observers, the reason was identified in the strong drop in growth of prices which reinforced the inclination for saving for Securities with a fixed rate able to guarantee stable remuneration.
} 
public deficit, and in the presence of a glaring reduction of inflation, the debt continued, however, to increase and it was still stably 'short', in the sense that it was strongly supported by the BOT people 7 . (Bastasin, 1986) In those years the 'families', (State bonds creditors), represented about $56 \%$ of the total of purchasers. Conversely, the cost of the debt was now equal to that of the transfers by the State to local authorities, social security and the health service.

Since the 1980s, the national debt has become in many ways the real regulator of the economy and consensus, at least until the early 1990s. In the years that followed, instead, debt policies have changed unavoidably. Later, this situation has made the Italian political system unable to react to external constraints imposed by the European Union in the mid-1990s. (Cavazzuti, 2014; Fabbrini, 2000; Giavazzi, Spaventa, 1988).

\section{References}

AIS, Archivio Istituto Luigi Sturzo, (1984). Verbali assemblee dei gruppi parlamentari della Democrazia Cristiana. Available online, SR (Senate of the Republic) website.

Amato G., Graziosi A., (2013). Grandi illusioni. Ragionando sull'Italia. Il Mulino, Bononia.

Andreatta B., Pandolfi F.M., (1980). Relazione sulla situazione economica del paese (1979) presentata al Parlamento dal ministro per il bilancio e la programmazione economica sen. Beniamino Andreatta e dal ministro per il Tesoro on. Filippo Maria Pandolfi. Istituto Poligrafico dello Stato, Rome.

Artoni R., (2003). Il debito pubblico in Italia dall'unità ad oggi, in: Ciocca P., Toniolo G., (Eds.). Storia economica d'Italia. Laterza, Roma-Bari, pp. 269-380.

Balassone F., Francese M., Pace A., (2013). Debito pubblico e crescita economica, in: Toniolo, G. (Ed.). L'Italia e l'economia mondiale dall'Unità a oggi. Marsilio, Venice, pp. 711-734.

Bastasin C., (1986). BOT a tutta forza (20.000 Miliardi). Rendimenti limati per i Cct e i Bpt di novembre. Il Sole 24 ore, 25 th October.

(http://www.archiviostorico.ilsole24ore.com/)

Brosio G., Marchese C., (1986). Il Potere di spendere. Economia e storia della spesa pubblica dall'Unificazione ad oggi. Il Mulino, Bononia.

Calise M. (1997). Il governo, in: Storia dell'Italia repubblicana, (vol. III/2). L'Italia nella crisi mondiale. L'ultimo ventennio. Einuadi, Turin, pp. 347-397.

Cama G., (2010). La Banca d'Italia. Il Mulino, Bononia.

Carabini 0. (1985). Tre soluzioni per diminuire l'onere del debito pubblico, Il Sole 24 ore, 15th August. (http://www.archiviostorico.ilsole24ore.com/)

Carli G., (2008). Intervista sul capitalismo italiano. E. Scalfari (Ed.). Bollati Boringhieri, Turin.

Cassese S., (2014). Governare gli Italiani. Storia dello Stato. Il Mulino, Bononia.

Cavazzuti F., (2014). La Repubblica in transizione (1989-94). Debito pubblico e fiscalità: le scelte politiche, in: S. Colarizi, A. Giovagnoli, P. Pombeni, (Eds.), L'Italia contemporanea dagli anni Ottanta a oggi, III, Istituzioni e politica. Carocci, Rome, pp. 159-184.

Censis, Centro Studi Investimenti Sociali, (1980). XIV rapporto/1980 sulla situazione sociale del paese. Censis, Rome.

Censis, (1983). XVII rapporto/1983 sulla situazione sociale del paese. Censis Rome.

Censis, (1987). XXI Rapporto/1987 sulla situazione sociale del paese. Censis, Milan

CC, (Court of Auditors), 1979. CD. Decisione e relazione della Corte dei conti. Rome. Available online, CD website.

CC, 1982, Decisione e relazione della Corte dei conti. Rome. Available online, CD website.

CC, 1986. CD. Decisione e relazione della Corte dei conti. Rome. Available online, CD website.

CD (Chamber of the Deputies), SR (Senate of the Republic), (1984). IX Legislatura, Quinta Commissione, Seduta congiunta del 2 ottobre. Rome. Available online, CD website.

CD, (1982). VIII Legislatura, Atti parlamentari, Discussioni, seduta del 26 novembre, pp. 54694-54695. Available online, CD website.

Crainz G., (2012). Il paese reale. Dall'assassinio di Moro all'Italia di oggi. Donzelli, Rome.

Craveri P., (2004). Dopo l'«Unità nazionale» la crisi del sistema dei partiti, in: Colarizi, S., Craveri, P., Pons, S., Quagliariello, G., (eds.). Gli anni Ottanta come storia. Rubbettino, Soveria Mannelli, pp. 11-30.

Craxi B., (2000). Discorsi parlamentari 1969-1993, Acquaviva (ed.). Laterza, Rome-Bari.

De Dominicis G., (1986). Stato illusionista, Il Sole 24 Ore, 22nd July.

(http://www.archiviostorico.ilsole24ore.com/)

Delalande N., (2011). Les batailles de l'impôt. Consentement et résistances de 1789 à nos jours. Seuil, Paris.

De Ioanna P., (1993). Parlamento e spesa pubblica. Il Mulino, Bononia.

\footnotetext{
${ }^{7}$ In addition, the rate at $12 \%$ surprised the Italian stock market.
} 
De Ioanna P. (2014), Debito pubblico e classe politica: uno sguardo d'insieme sulla Prima Repubblica, in: S. Colarizi, A. Giovagnoli, P. Pombeni, (eds.), L'Italia contemporanea dagli anni Ottanta a oggi, III, Istituzioni e politica. Carocci, Rome, pp. 141-158.

Downs A., (1957). An Economic Theory of Democracy. Harper, New York.

Ferguson N., Maier C.S., Manela E., Sargent D.J., (Eds.), (2010), The Shock of the the Global. The 1970s in Perspective. Harvard University Press, Cambridge MA.

Fabbrini S., (2000). Parlamento, Governo e Capo del Governo, in: Di Palma G., Fabbrini S.,

Freddi G., (Eds.), Condannata al successo? L'Italia nell'Europa integrata. Il Mulino, Bononia, pp. 45-78.

Franco D., (1993). L'espansione della spesa pubblica in Italia. Il Mulino, Bononia

Fausto D., (2007). La politica del debito pubblico dell'Italia repubblicana nelle Relazioni della Banca d'Italia, in: De Luca G., Moioli A. (Eds.), Debito pubblico e mercati finanziari in Italia secoli XIII-XX. FrancoAngeli, Milano, pp. 661-697.

FBC, Fondazione Bettino Craxi, (1984), Fondo Bettino Craxi, Presidenza del Consiglio dei Ministri, Definizione e attuazione del programma di Governo, verifica politica del luglio. Available online, SR website.

Francese M., Pace A., (2008). Il debito pubblico italiano dall'Unità ad oggi. Una ricostruzione della serie storica. Questioni di Economia e Finanza (Banca d'Italia), 31.

Giavazzi F., Spaventa L. (Eds.) (1988). High Public Debt: the Italian Experience. Cambridge University Press, Cambridge (UK).

Goria G.(1985). Politiche e obiettivi per il controllo della finanza pubblica, Rome, 22nd May, (dossier of the Ministero del Tesoro).

Goria G., (2004). Discorsi parlamentari (1976-1992). Tanda A.P., (Ed.). Camera dei Deputati, Rome.

Heller W.B., (1997). Bicameral and Budget Deficits: The Effect of Parliamentary Structure on Government Spending, Legislative Studies Quarterly, XXII (4), pp. 485-516.

Lanzalaco L., (2005). Le politiche istituzionali. Il Mulino, Bononia.

Ledda R. (1984), Interview with Alfredo Reichlin, L'Unità, 2nd September. (http://archivio.unita.it)

Locatelli P. (1985), Craxi rifà i conti: l'85 non é perduto, Il Sole 24 ore, 9th May.

(http://www.archiviostorico.ilsole24ore.com/)

Marinelli M.L., (2011). L'indipendenza della Banca d'Italia dal governo negli anni Ottanta: cause interne e internazionali, Studi e note di economia, XVI (2), pp. 133-170.

Mastropaolo A., (1996), La repubblica dei destini incrociati. Saggio su cinquant'anni di democrazia in Italia. La Nuova Italia, Florence.

Merli A. (1984), Banca d'Italia: il 7\% è un tetto obbligato, II Sole 24 ore, 17 th November.

(http://www.archiviostorico.ilsole24ore.com/)

Pandolfi F.M., (2000). L’uomo di governo, in: Toria C., Zorzi R., (Eds.), Per Bruno Visentini. Marsilio, Venice, pp. 47-70.

M. Riva (1979). Contro lo Stato per riconquistarlo, Corriere della Sera, 13th May.

(http://archivio.corriere.it)

Romanelli R. (Ed.) (1997). Storia dello Stato italiano. Dall’Unità ad oggi. Donzelli, Rome.

Salvati M. (2000). Occasioni mancate. Economia e politica in Italia dagli anni '60 a oggi. Laterza, Rome-Bari.

Salvemini M.T. (1992). Le politiche del debito pubblico. Laterza, Rome-Bari.

Salsano F. (2009). Andreatta Ministro del Tesoro. Il Mulino, Bononia.

Santagata W. (1995). Economia, elezioni, interessi. Un'analisi dei cicli economici elettorali in Italia. Il Mulino, Bononia.

Spadolini G. (2002). Discorsi parlamentari. Ceccuti, C. (Ed.). Il Mulino, Bononia.

SR (1978), VIII Legislatura, Decisione e relazione della Corte dei Conti sul rendiconto generale dello Stato per l' esercizio finanziario. Available online, SR website.

SR, CD (1982), VIII Legislatura, Disegni di legge e Relazioni, Documenti. Available online, SR, CD website.

SR (1985/1). IX Legislatura, Giunte e commissioni parlamentari, 425 Resoconto, sessions of Thursday 7 th November.

SR (1985/2). IX Legislatura, Atti parlamentari, 373a Seduta pubblica del 28 novembre. Available online, SR website.

SR (1985/3). IX Legislatura, Commissione permanente, disposizioni per la formazione del bilancio annuale e pluriennale dello Stato (legge finanziaria 1986), seduta del 9th October. Available online, SR website.

SR, CD, (1984). IX Legislatura, Relazione della Corte dei Conti sul rendiconto generale dello Stato per l'esercizio finanziario. Available online, SR website.

Streeck W. (2013). Die Vertagte Krise des demokratischen Kapitalismus. Suhrkamp Verlag, Berlin.

Tanzi V., Schuknecht L., (2000). Public Spending in the 20th Century. A Global Perspective. Cambridge University Press, Cambridge (UK).

Valente A. (ed.) (1990). Da Einaudi a Ciampi. Le considerazioni finali dei governatori della Banca d'Italia 1947 1986. Laterza, Roma-Bari.

Verzichelli L., (1999). Le politiche di bilancio. Il Mulino, Bononia. 